\title{
Observations on permafrost ground thermal regimes from Antarctica and the Italian Alps, and their relevance to global climate change
}

\author{
Guglielmin Mauro* \\ University of Insubria, Via J.H. Dunant 3, 21100 Varese, Italy \\ Received 7 November 2001; accepted 7 May 2003
}

\begin{abstract}
Active-layer monitoring and the permafrost thermal regime are key indicators of climate change. The results of 3 years (1997-1999) of active-layer monitoring at one high-mountain site (La Foppa, $46^{\circ} 28^{\prime} 42^{\prime \prime} \mathrm{N} ; 10^{\circ} 11^{\prime} 18^{\prime \prime} \mathrm{E}, 2670 \mathrm{~m}$ a.s.1.) and at one Antarctic site (Boulder Clay, $74^{\circ} 44^{\prime} 45^{\prime \prime} \mathrm{S} ; 164^{\circ} 01^{\prime} 17^{\prime \prime} \mathrm{E}, 205 \mathrm{~m}$ a.s.l) are presented. The initial analysis of a thermal profile in a borehole ( $100.3 \mathrm{~m}$ deep) within mountain permafrost at Stelvio ( $3000 \mathrm{~m}$ a.s.1., $46^{\circ} 30^{\prime} 59^{\prime \prime} \mathrm{N}$; $\left.10^{\circ} 28^{\prime} 35^{\prime \prime} \mathrm{E}\right)$ is also presented. At the alpine site, the active-layer thickness variations (between 193 and $229 \mathrm{~cm}$ ) relate to both the snow cover and to the air temperature changes. By contrast, at the Antarctic site, there is a strong direct linkage only between air temperature fluctuations and active-layer variations. At the alpine (La Foppa) site, the relationship between climate and active-layer thickness is complicated by thermal offset that is almost negligible at both the Stelvio and Antarctic sites. The permafrost temperature profile at Stelvio site contains a climate signal suitable for paleoclimate reconstruction. The permafrost at this site has a mean annual ground surface temperature (MAGST) of $-1.9{ }^{\circ} \mathrm{C}$ (during 1998/1999), an active layer of about $2.5 \mathrm{~m}$ thick and a total thickness of $\sim 200 \mathrm{~m}$. Analysis of the MAGST history, obtained by applying a simple heat conduction one-dimensional model, revealed the occurrence of a cold period from 1820 to 1940 followed by a warming period until 1978. Since the beginning of the 1980 s, temperature dropped (less than $2{ }^{\circ} \mathrm{C}$ ) until the middle $1990 \mathrm{~s}$, when a new period of warming started. All these climatic changes fit well with the glacial fluctuations in the area and with other paleoclimatic information derived from different proxy data.
\end{abstract}

(C) 2003 Elsevier B.V. All rights reserved.

Keywords: Permafrost; Active Layer; Climate Change; Paleoclimate

\section{Introduction}

Several methods can be used to derive paleoclimatic information at different time scales in permafrost environment. The monitoring of the active-layer thick-

* Tel.: +39-0332-421523; fax: +39-0332-421331.

E-mail address: mauro.guglielmin@uninsubria.it (G. Mauro). ness and ground temperature profiles provide faithful records of surface temperature present and past changes. This is because the active-layer thickness records the seasonal and annual variations of ground surface temperature (GST) (e.g., Guglielmin and Dramis, 1999; Nelson et al., 1998; Nixon and Taylor, 1998; Burgess et al., 2000).

The analysis of temperature profiles within permafrost provides information about the changes of sur- 
face temperature at time scales between decades to millennia depending on the depth of the examined profiles $(20 / 30-300 / 400 \mathrm{~m})$ and on the thermal properties of the site (e.g., Lachembruch and Marshall, 1986).

The ground surface temperature (GST) reflects the net energy balance at the surface, which depends upon several climatic factors such as air temperature, incoming radiation and snow cover. The temperature propagation from the surface to the interior depends upon the thermal properties of the ground that filter and smooth the temperature signal.

\section{Data sets}

Two data sets come from the Valtellina (Italian Central Alps). The first is an active-layer monitoring site $\left(46^{\circ} 28^{\prime} 42^{\prime \prime} \mathrm{N} ; 10^{\circ} 11^{\prime} 18^{\prime \prime} \mathrm{E}, 2670 \mathrm{~m}\right.$ a.s.l.) located on the frontal part of an active rock glacier (La Foppa I). The second is an alpine permafrost thermal monitoring site located on outcropping dolostone bedrock, near the Livrio glacier cable car station Stelvio, at 3000 $\mathrm{m}$ a.s.l. $\left(46^{\circ} 30^{\prime} 59^{\prime \prime} \mathrm{N} ; 10^{\circ} 28^{\prime} 35^{\prime \prime} \mathrm{E}\right)$. The third data set is an active-layer monitoring site located in an icefree area of Northern Victoria Land, Antarctica, referred to as Boulder Clay Glacier a few kilometres from the Italian Antarctic Research Station (PNRA) of Terra Nova Bay $\left(74^{\circ} 44^{\prime} 45^{\prime \prime} \mathrm{S}\right.$; - $164^{\circ} 01^{\prime} 17^{\prime \prime} \mathrm{E}, 205$ m a.s.l) (Fig. 1).

\section{Methods}

The active-layer monitoring can be done both through the automatic and continuous measurements
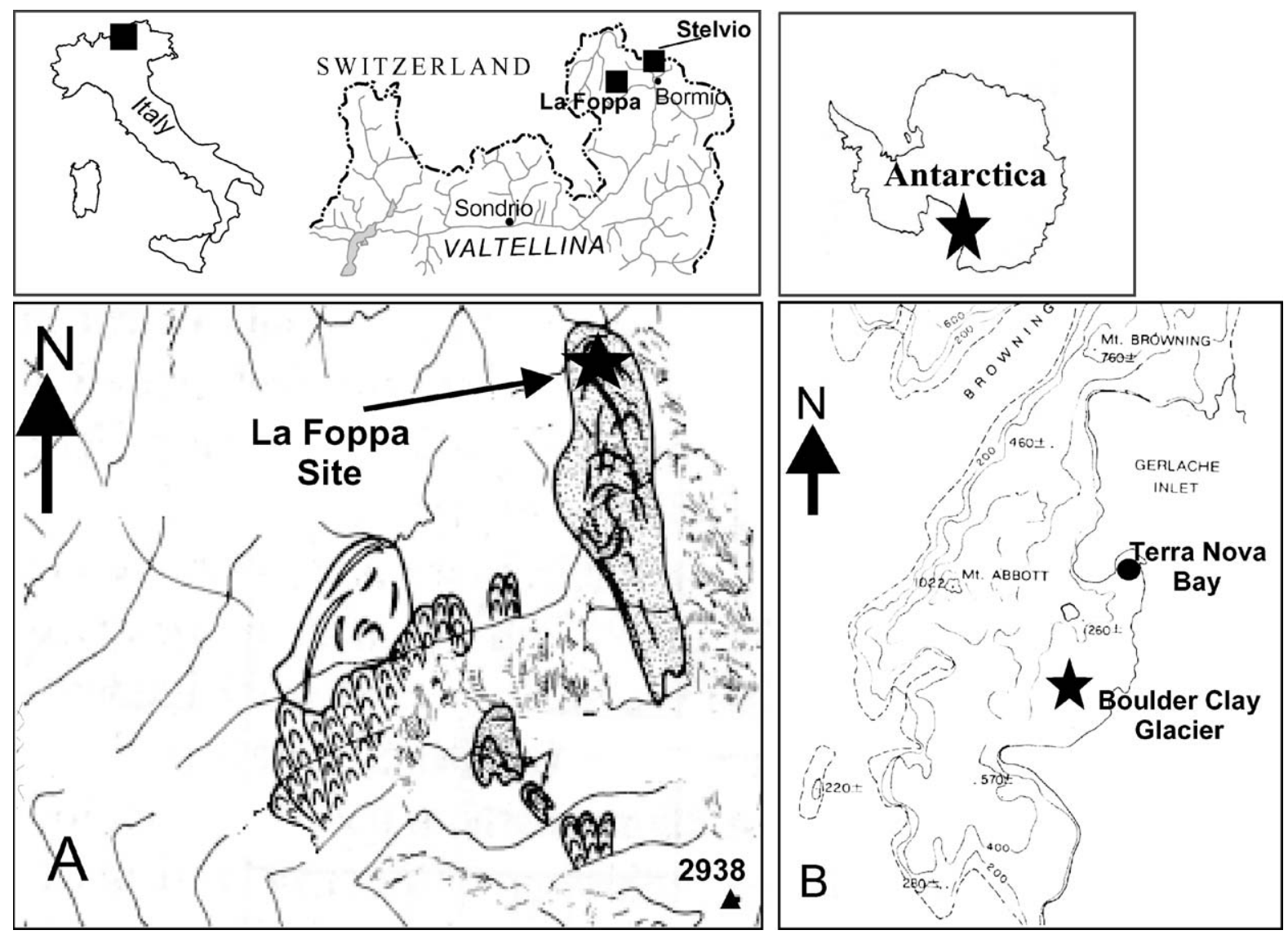

Fig. 1. Study areas: (A) La Foppa site, (B) Boulder Clay Glacier site. 
of temperature at different depths, or by annual probings of the maximum thickness of seasonal thaw.

In all sites, monitoring was carried out because the coarse sediments that characterise the sites make probing almost impossible and certainly inaccurate.

At the monitoring sites, thermistors were installed at 2, 3050,150 and $300 \mathrm{~cm}$ (La Foppa) and at 2, 30, $60,160,260$ and $360 \mathrm{~cm}$ (Boulder Clay Glacier). The upper two setted directly in the ground, parallel to the surface while the deeper ones installed in boreholes cased with a lining of plastic tube and insulated from each other with clay packs. The thermistors have accuracies of $\pm 0.1{ }^{\circ} \mathrm{C}$ and a resolution of $0.01{ }^{\circ} \mathrm{C}$. Temperatures were measured every $10 \mathrm{~min}$. However, only the minimum, maximum and average values were recorded by dataloggers every $30 \mathrm{~min}$ at La Foppa and every $1 \mathrm{~h}$ at Boulder Clay Glacier.

As regards permafrost thermal data, the site chosen was one where the outcropping bedrock is homogenous, being composed of subvertical dolostone layers with thin limestone intercalations, without appreciable changes in thermal properties. Topographic effects are also limited because the summit is subrounded without sharp cliffs or very steep slopes close to the borehole.

The thermal regime of the borehole was monitored with thermometers according to the PACE protocol (Harris et al., 2001). Temperatures were measured and recorded by a datalogger every hour along the entire borehole.

\section{Results and analyses}

\subsection{Active-layer monitoring}

Fig. 2 shows the daily averages of temperature recorded at the La Foppa 1 site at 2-cm and 3-m depths, respectively, between 1997 and 1999. The 3 years show similar annual trends at $2 \mathrm{~cm}$, even if there are great changes in absolute values both in the summer and during the fall freezing period. At 3-m depth, the temperature pattern shows the usual phase lag and smoothing of the temperature amplitude, although the duration of the "zero curtain effect" changes yearly.

Fig. 3 shows the daily averages of temperature recorded at Boulder Clay Glacier site at the 2- and the $30-\mathrm{cm}$ depths, respectively, for the same period. The Antarctic site is distinctive with its lack of the "zero curtain effect" and its great variation in summer temperatures at both depths.

The active-layer thickness was calculated according to Gold and Lachenbruch (1973):

$h l=\left[k P / \pi \ln \left|A_{0} / T_{0}\right|\right] 1 / 2$

where $k$ is the thermal diffusivity of the ground, $P$ is the period of the thermal cycle, $A_{0}$ is the surface temperature amplitude and $T_{0}$ is the mean annual ground surface temperature (MAGST). Table 1 shows the thermal diffusivity $\left(\mathrm{m}^{2}\right.$ day $\left.^{-1}\right)$ and the active-

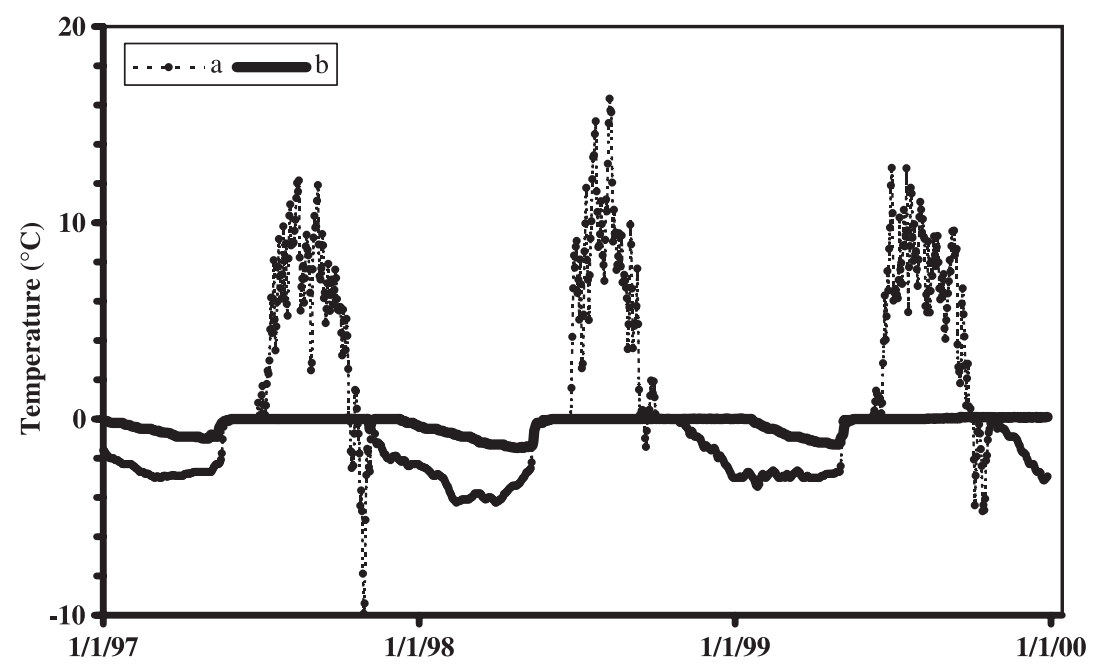

Fig. 2. Daily ground temperature values recorded at La Foppa between 1 January 1997 to 31 December 1999: (a) 2-cm depth, (b) 3-m depth. 


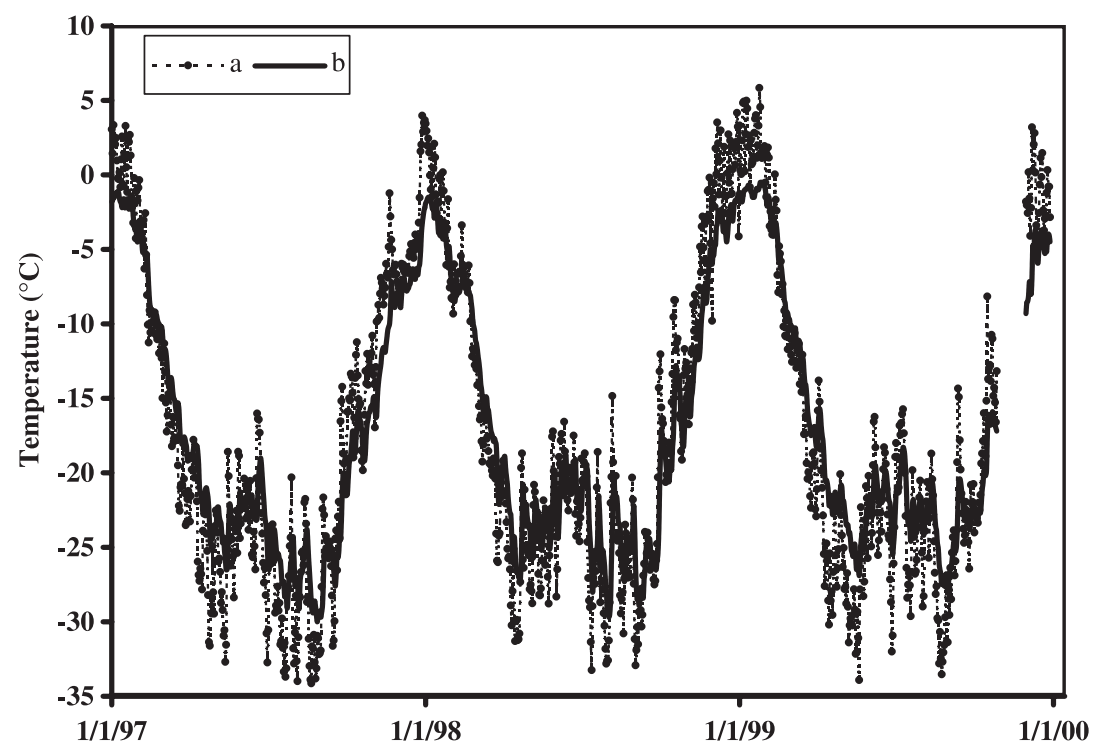

Fig. 3. Daily ground temperature values recorded at Boulder Clay Glacier between 1 January 1997 to 31 December 1999: (a) 2-cm depth, (b) 30cm depth.

layer thickness calculated using Eq. (1) (Alc) and by applying the simple linear interpolation of the measured temperatures at the different depths (Ale).

Certain other climatic elements such as air temperature, snow cover and incoming radiation are usually measured in order to understand the relationship between surface and ground temperatures and climate.

Therefore, Fig. 4 shows the air temperature for the Alpine and Antarctic sites for the same period. They show similar trends with maximum amplitudes very similar (around $40{ }^{\circ} \mathrm{C}$ ). Linear regressions, calculated between daily averages of surface and air temperature for both sites, are reported in Table 2. It is remarkable that the Antarctic site always shows a very good

Table 1

Thermal diffusivities and active layer thickness calculated according to Eq. (1) (ALc) and estimated by simple interpolation of temperature profile (ALe) for La Foppa site (1) and Boulder Clay Glacier site (2)

\begin{tabular}{lccc}
\hline & 1997 & 1998 & 1999 \\
\hline $1 k\left(\mathrm{~m}^{2} \mathrm{~s}^{-1}\right)$ & $9.14 \times 10^{-8}$ & $1.26 \times 10^{-7}$ & $1.39 \times 10^{-7}$ \\
$2 k\left(\mathrm{~m}^{2} \mathrm{~s}^{-1}\right)$ & $1.89 \times 10^{-7}$ & $1.18 \times 10^{-7}$ & $1.69 \times 10^{-7}$ \\
1 Alc $(\mathrm{m})$ & 189 & 220 & 224 \\
1 Ale $(\mathrm{m})$ & 193 & 229 & 215 \\
2 Alc $(\mathrm{m})$ & 36 & 29 & 33 \\
2 Ale $(\mathrm{m})$ & 21 & 18 & 25 \\
\hline
\end{tabular}

correlation between surface and air temperature (with an $R^{2}>0.9$ ), while the alpine site does not show such a good correlations (with an $R^{2}<0.5$ ). This indicates that in alpine conditions other climatic elements can influence the surface temperature, especially the snow cover. The variability in permanence and thickness of the snow cover at La Foppa is illustrated in Fig. 5. This explains the changes of surface temperature that do not correlate with air temperature.

\subsection{Borehole thermal monitoring in permafrost}

At the Stelvio permafrost monitoring site in 1999, the MAGST was $-1.9{ }^{\circ} \mathrm{C}$ and the active layer was about $2.5 \mathrm{~m}$ thick with a mean annual permafrost temperature (MAPST) of $-1.7{ }^{\circ} \mathrm{C}$.

Fig. 6 shows the thermal profile recorded 1 year after drilling. The profile is clearly not linear, showing different thermal gradients with the depth. The interpretation of the thermal regime within permafrost can be treated by applying heat conduction theory (Carlsaw and Jaeger, 1959) and considering the topographical characteristics of the site; it can be solved using a one-dimensional model. The depth of permafrost around $200 \mathrm{~m}$ was estimated by applying a linear extrapolation and using the mean thermal gradient measured in the borehole $\left(6.44 \times 10^{-3}{ }^{\circ} \mathrm{C} \mathrm{m}^{-1}\right)$. 


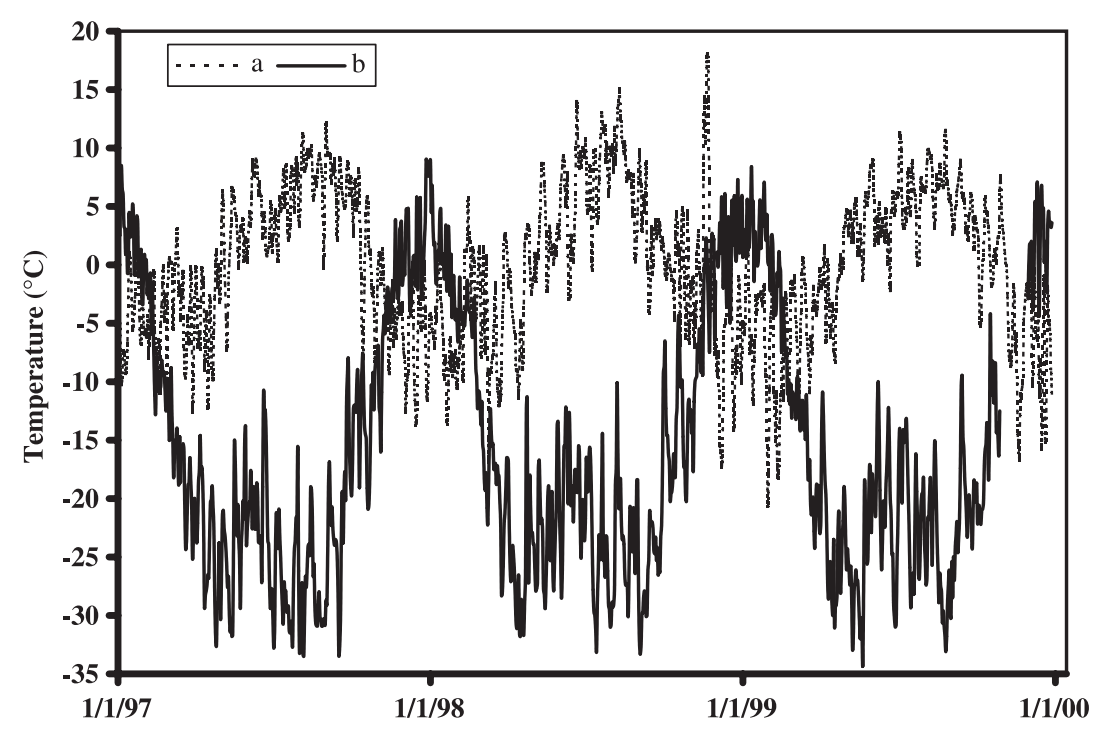

Fig. 4. Daily air temperature values recorded at La Foppa (a) and Boulder Clay Glacier (b) from 1 January 1997 to 31 December 1999.

The geological structure of the site excludes great lithological changes and for this reason, the thermal conductivity and the heat flow were assumed homogeneous with depth. The values of thermal diffusivity were calculated in the zone of seasonal temperature variations (i.e. upper $13 \mathrm{~m}$ ) according to Carlsaw and Jaeger (1959), applying both the amplitude attenuation with depth (Eq. (2)) and the phase lag with depth (Eq. (3)):

$k_{\mathrm{a}}=\pi / P\left[\left(z_{2}-z_{1}\right) / \ln \left(A_{1} / A_{2}\right)\right]^{2}$

$k_{\mathrm{p}}=P / 4 \pi\left[\left(z_{2}-z_{1}\right)^{2}\left(t_{2}-t_{1}\right)^{-2}\right]$

where $k$ is the ground thermal diffusivity, $P$ is the time period of the thermal wave considered (days), $z_{1}$ and $z_{2}$ are the measuring depths, $A_{1}$ and $A_{2}$ are the amplitudes of the temperature variations at $z_{1}$ and $z_{2}$

Table 2

Linear regressions between daily means values of air temperature and GST for La Foppa site (1) and Boulder Clay Glacier site (2)

\begin{tabular}{llll}
\hline & 1997 & 1998 & 1999 \\
\hline $1 \quad y=1.0799 x-0.383$, & $y=0.98 x+0.0178$, & $y=0.9649 x-1.031$, \\
& $R^{2}=0.589$ & $R^{2}=0.461$ & $R^{2}=0.444$ \\
2 & $y=1.0913 x-3.603$, & $y=0.941 x-0.115$, & $y=0.9849 x+0.834$, \\
& $R^{2}=0.962$ & $R^{2}=0.913$ & $R^{2}=0.975$ \\
\hline$y=$ MAGST and $x=$ MAAT. &
\end{tabular}

and $t_{2}-t_{1}$ is the phase lag during the period $P$. The results are illustrated in Table 3 .

The thermal diffusivity is related to the thermal conductivity according to Eq. (4), as illustrated by Gold and Lachenbruch (1973):

$k=K / c \rho$

where $c$ (mass specific heat capacity) and $\rho$ (density) are, for dolostone, $730 \mathrm{~J} \mathrm{~kg}^{-1} \mathrm{~K}^{-1}$ and $2600 \mathrm{~kg} \mathrm{~m}^{-3}$, respectively (Gregnanin, 1980). According to Eq. (4) and using the results reported in Table 3, the thermal conductivity $(K)$ values range between 1.51 and 3.53 $\mathrm{W} \mathrm{m}{ }^{-1} \mathrm{~K}^{-1}$.

The reconstruction of the ground surface temperature (GST) is possible using different type of models (Cermak, 1971; Lachembruch and Marshall, 1986; Wang, 1992). In this case, the inversion procedure was carried out with a code based on the Bayesian inverse technique to estimate the GST history (see Wang, 1992 for a detailed description). According to Osterkamp and Gosink (1991), the time required $\left(t_{\mathrm{c}}\right)$ for the temperature profile within permafrost to adjust to a surface temperature change follows the equation:

$t_{\mathrm{c}}=X^{2} / 4 k$

where $X$ is the permafrost thickness and $k$ is its thermal diffusivity. In the Stelvio case, considering the diffu- 


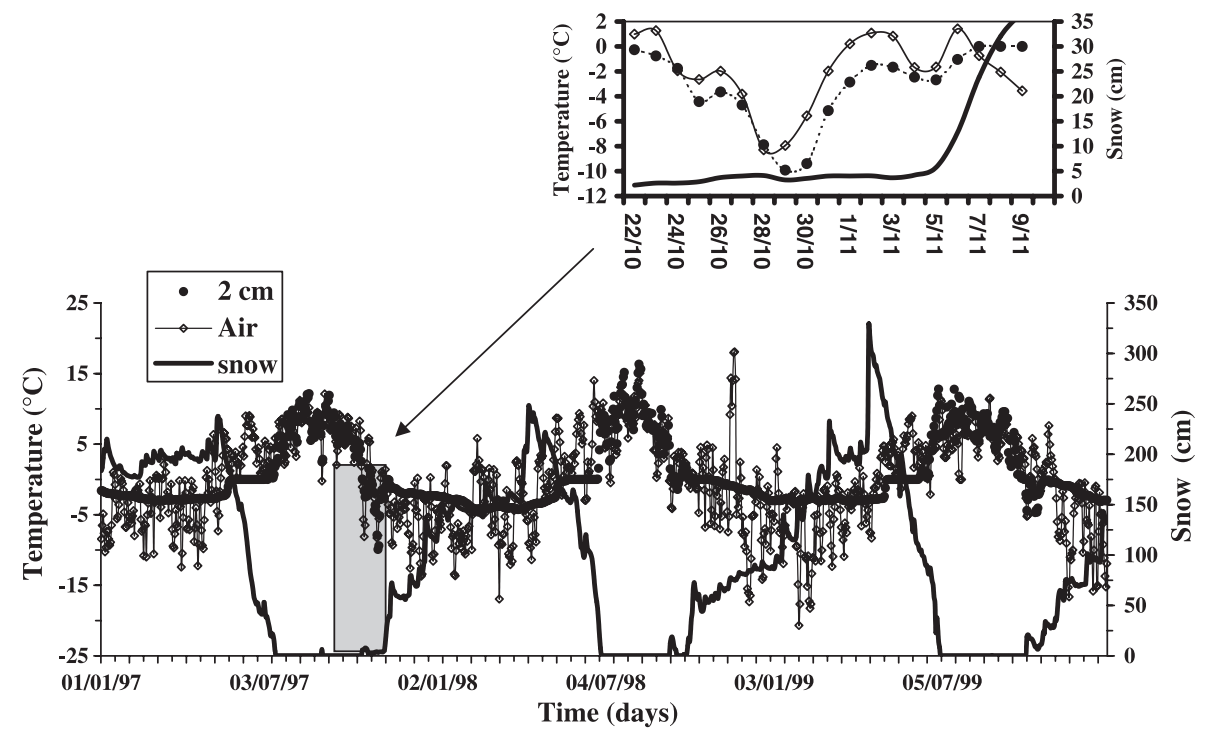

Fig. 5. Relationships between snow cover depth, daily air and ground at 2-cm temperatures at La Foppa site from 1 January 1997 to 31 December 1999. Please note the box where it is possible to observe better the effect of a very thin snow cover on the ground temperature during Fall.

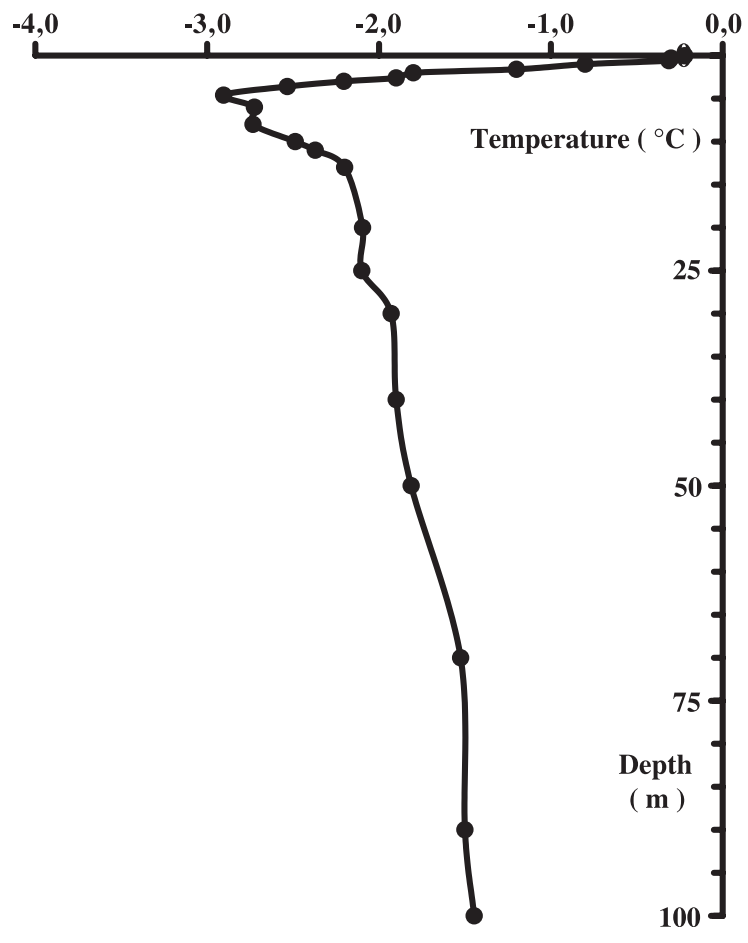

Fig. 6. Temperature profile at Stelvio permafrost borehole recorded on 5 June 1999, 1 year after drilling. sivities of Table $3, t_{\mathrm{c}}$ should be between 200 and 300 years. To obtain the best fitting between the measured temperature profile and the modelled one, different combinations of thermal properties ( $K$ and $k$ ) obtained by the results of Table 3 and Eq. (4), and time period have been considered. In all the cases, a heat ground flow of $85 \mathrm{~mW} \mathrm{~m}^{-2}$ (Cermak et al., 1992) was used. The two best profiles are obtained both with a time period of 200 years, the first with a $K$ of $2.65 \mathrm{~W} \mathrm{~m}^{-1}$ $\mathrm{K}^{-1}$ and a $k$ of $1.39 \times 10^{-6} \mathrm{~m}^{2} \mathrm{~s}^{-1}$, the second with a $K$ of $3.53 \mathrm{~W} \mathrm{~m}^{-1} \mathrm{~K}^{-1}$ and a $k$ of $1.87 \times 10^{-6} \mathrm{~m}^{2} \mathrm{~s}^{-1}$. Fig. 7 shows the results of the GST reconstruction of these two cases with a standard deviation of GST of 1 .

Data for the longest available record of mean annual air temperature (MAAT) in the surrounding area of the borehole is recorded at Silandro, a locality

Table 3

Thermal diffusivities (m) $k_{\mathrm{a}}$ and $k_{\mathrm{p}}$ calculated, respectively, according the Eqs. (2) and (3) at different depths in the upper $13 \mathrm{~m}$ of the Stelvio permafrost borehole

\begin{tabular}{lrlrr}
\hline & $0.3-3(\mathrm{~m})$ & $3-6(\mathrm{~m})$ & $6-10(\mathrm{~m})$ & $10-13(\mathrm{~m})$ \\
\hline$k_{\mathrm{a}}\left(\mathrm{m}^{2} \mathrm{~s}^{-1}\right)$ & $8.4 \times 10^{-7}$ & $1.99+10^{-6}$ & $8.2 \times 10^{-7}$ & $1.8 \times 10^{-6}$ \\
$k_{\mathrm{p}}\left(\mathrm{m}^{2} \mathrm{~s}^{-1}\right)$ & $2.45 \times 10^{-7}$ & $1.39 \times 10^{-6}$ & $6.57 \times 10^{-7}$ & $1.87 \times 10^{-6}$ \\
\hline
\end{tabular}




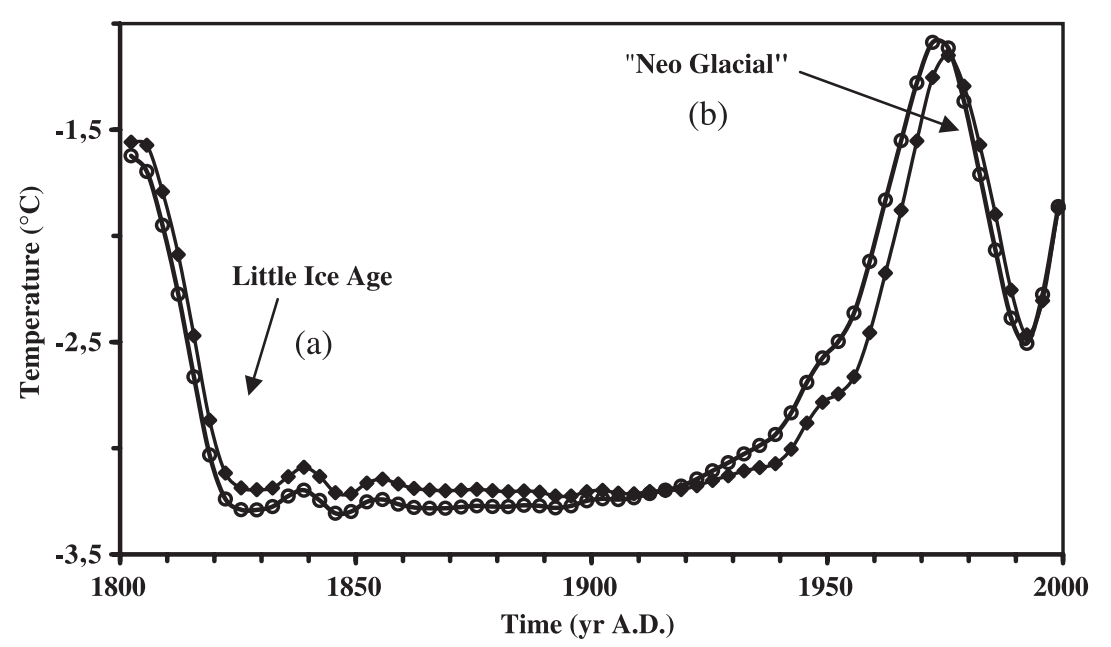

Fig. 7. GST reconstructions applying a simple heat conduction, one-dimensional model (see the text the details). The arrows mark the beginning of the maximum glacial advance during the Little Ice Age (1821) and the "NeoGlacial" (1978) in the study area. Curve (a) was calculated with $K=2.65 \mathrm{~W} \mathrm{~m}^{-1} \mathrm{~K}^{-1}$ and $k=1.39 \times 10^{-6} \mathrm{~m}^{2} \mathrm{~s}^{-1}$, while curve (b) with $K=3.53 \mathrm{~W} \mathrm{~m}^{-1} \mathrm{~K}^{-1}$ and $k=1.87 \times 10^{-6} \mathrm{~m}^{2} \mathrm{~s}^{-1}$.

a few kilometers north of the borehole at an altitude of 720 m a.s.l. To compare these MAAT values with the obtained GST, the first were multiplied by the mean lapse rate for the area $\left(0.6{ }^{\circ} \mathrm{C} / 100 \mathrm{~m}\right)$ to have a theoretical MAAT values at $3000 \mathrm{~m}$ a.s.l.

\section{Discussion}

The results illustrated in Figs. 2-4 enhance the different relationships between GST and climate in the continental Antarctica and in the Alps. In the first case, the linkage between air temperature and GST is direct; in the second, the buffering effect of the snow cover negates a simple correlation between air temperature and GST.

The snow cover exerts a buffering effect that insulates the ground surface by any possible heat exchanges with the atmosphere when the cover is thick enough. It is clear that variations in snow distribution have opposite effects on the GST. An increase in snow cover during spring prevents warming of the ground thereby reducing the GST, while a thick snow cover in Fall prevents cooling of the ground, thereby raising the GST. This is well known in the Arctic (e.g., Nicholson and Granberg, 1973; Smith, 1975).

Fig. 5 shows another effect of snow cover. During the Fall 1997, the GST reached values $2{ }^{\circ} \mathrm{C}$ lower than air temperature $\left(-9.91\right.$ and $-7.94{ }^{\circ} \mathrm{C}$, respectively) with a very thin snow cover $(3 \mathrm{~cm})$. A very thin snow cover increases the heat flow, from the ground through snow cover to the atmosphere because the snow surface has a radiative balance much more negative (less short wave absorbed and more outcoming long wave) than the ground surface, as already demonstrated by Keller and Gubler (1993) in another alpine site.

The same effect of snow can explain why the GST at the Antarctic site is often lower than the air temperature during the summer. In addition, during the winter, the GST is often lower than the air temperature: in this case, it is hypothesized that the buffering effect of a thick snow cover prevents heating when relatively warm sea air reaches the continent (Guglielmin and Dramis, 1999). Unfortunately, at the moment, there is insufficient snow thickness data in the study area to confirm this hypothesis.

The active layer correlates well with climate at the Antarctic site where the "thermal offset", defined according to Romanovsky and Osterkamp (1995) as the difference between MAGT and MAPT measured at the permafrost table, is small. However, the alpine site shows a thermal offset that is much more pronounced: this may be caused by the coarse debris layer that characterises the upper $2 \mathrm{~m}$ of the subsurface material. The processes that occur in this coarse debris mantle, for example, the Balch effect (Harris 
and Pedersen, 1998), are not well-known and need further detailed investigation.

Analysis of the GST history (Fig. 7) indicates the occurrence of a warm period, which ended, when the Little Ice Age began. These data confirm dendrochronological results obtained from the surrounding areas (Pelfini, 1999) for the Little Ice Age. The evolution of glaciers in the Ortles-Cevedale group (Pelfini, 1992) fits well with the warming period marked by GST at the beginning of the 1940s, followed by the sharp drop in temperature since 1978. This corresponds to the glacier advance called the "NeoGlacial period" (Pelfini, 1992), a period in which almost all glaciers in the area advanced. Comparing the GST data obtained by Isaksen et al. (2001) for the Jannssonhaugen borehole in Svalbard with the Stelvio data, it can be seen that they are in good agreement until the 1960s. At that time, the "Neoglacial period" started earlier in the Arctic.

The poor relationships between air temperature and GST show in Fig. 8 can be explained by the strong buffering effect of the snow that is effective at this site, as at La Foppa. The trend of MAAT 30-year moving average is more similar to the GST than to the MAAT because the atmospheric high frequency signal is completely filtered by the ground; the latter only records low-frequency events. During the 1950 s, the MAAT 30-year moving average slightly drops while the GST increases. The warmer GST, $\sim 1.5-2{ }^{\circ} \mathrm{C}$ with respect to the MAAT, could be explained by the snow cover insulation of the during the fall and by high incoming solar radiation in the summer on a high summit like the Stelvio.

\section{Conclusion}

The results of the active-layer monitoring of an alpine site (La Foppa) and of an Antarctic site (Boulder Clay Glacier) demonstrate that the active layer is a good climate impact indicator, both in the Antarctic and in high altitude Alpine environments.

The active-layer variations in the Alpine sites relate both to air temperature and to snow cover, while in the Antarctic there is a clear direct linkage only with air temperature. At La Foppa, the relationships between climate and active-layer thickness are complicated by a thermal offset that is negligible in the Stelvio borehole site. The temperature profile at the Stelvio site contains a preserved climate signal suitable for the paleoclimate reconstruction. Analysis of the GST history obtained

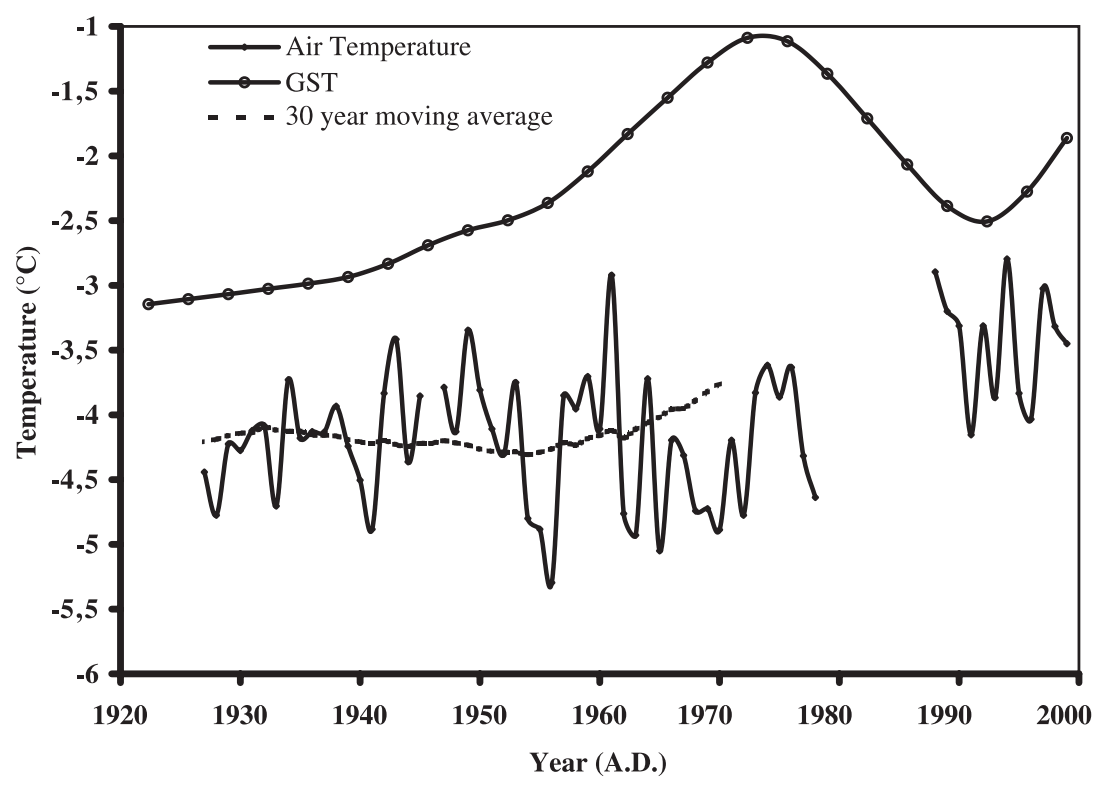

Fig. 8. Comparison between MAAT and the MAGST at Stelvio borehole. The high-frequency events of MAAT are filtered by the ground; in fact, the 30 years moving average of the MAAT is more comparable with the MAGST. 
by applying a simple heat conduction one-dimensional model fits well with the paleoclimatic reconstruction of the last two centuries in the Italian Central Alps achieved through other proxy data.

\section{Acknowledgements}

Research was made possible by funds from the project Permafrost and Global Change in Antarctica, supported by the Italian National Antarctic Project (PNRA), and from the project Permafrost and Climate in Europe (PACE), supported by the European Commission (contract ENV4-CT97-0492). Special thanks go to the Centro Nivometereologico di Bormio of Regione Lombardia that provided the La Foppa data, and to T. Kohl of the Institute of Geophysics of Zurich University that wrote the software to reconstruct the paleotemperature. The manuscript has been deeply improved by the useful comments of H.M. French and N. Shiklomanov, especially regarding the english language.

\section{References}

Burgess, M., Smith, S.L., Brown, J., Romanovsky, V., Hinkel, K., 2000. Global Terrestrial Network for Permafrost (GTN-P): permafrost monitoring contributing to global climate observations. Geological Survey of Canada, 1-8 (Current Research 2000-E14).

Carlsaw, H.S., Jaeger, J.C., 1959. Conduction of Heat in Solids. Oxford Univ. Press, New York. 510 pp.

Cermak, V., 1971. Underground temperature and inferred climatic temperature of the past millenium. Palaeogeography, Palaeoclimatology, Palaeoecology 10, 1-19.

Cermak, V., Balling, N., Della Vedova, B., Lucazeau, F., Pasquale, V., Pellis, G., Schulz, R., Verdoya, M., 1992. Heat-flow data (Italy). In: Blundell, D., Freeman, R., Mueller, St. (Eds.), A Continent Revealed: The European Geotraverse Database. Cambridge Univ. Press, Cambridge, pp. 49-57.

Gold, L.W., Lachenbruch, A.H., 1973. Thermal conditions in permafrost: a review of North American literature. 2nd International Permafrost Conference, 13-28 July 1973, Yakutsk, U.S.S.R. National Academy of Sciencies, Washington, DC, pp. 3-25. North American contribution.

Gregnanin, A., 1980. Petrografia Applicata: 1. Università di Milano Pubbl., Milano. 240 pp.

Guglielmin, M., Dramis, F., 1999. Permafrost as a climatic indicator in northern Victoria Land, Antarctica. Annals of Glaciology 29, $131-135$.
Harris, S.A., Pedersen, D.E., 1998. Thermal regimes beneath coarse blocky material. Permafrost and Periglacial Processes 9, $107-120$.

Harris, C., Haeberli, W., Vonder Mühll, D., King, L., 2001. Permafrost monitoring in the high mountains of Europe: the PACE Project in its global context. Permafrost and Periglacial Processes 12, 3-11.

Isaksen, K., Vonder Mühll, D., Gubler, H., Kohl, T., Sollid, J.L., 2001. Ground surface-temperature reconstruction based on data from a deep borehole in permafrost at Janssonhaugen, Svalbard. Annals of Glaciology 31, 287-294.

Keller, F., Gubler, H., 1993. Interaction between snow cover and high mountain permafrost, Murtel-Corvatsch, Swiss Alps. 6th International Conference on Permafrost, Beijing, China, vol. 1. South China University of Technology Press, Beijing, pp. $332-337$.

Lachembruch, A.H., Marshall, B.V., 1986. Changing climate: geothermal evidence from permafrost in the Alaskan Arctic. Science $234,689-696$.

Nelson, F.E., Outcalt, S.I., Brown, J., Shiklomanov, N.I., Hinkel, K.M., 1998. Spatial temporal attributes of the active-layer thickness record, Barrow, Alaska, USA. 7th International Conference on Permafrost, Yellowknife, Canada. Centre d'études nordiques, Université Laval, pp. 797-802.

Nicholson, F.H., Granberg, H.B., 1973. Permafrost and snowcover relationships near Schefferville. 2nd International Permafrost Conference, 13-28 July 1973, Yakutsk, U.S.S.R. National Academy of Sciencies, Washington, DC, pp. 151-158. North American contribution.

Nixon, F.M., Taylor, A.E., 1998. Regional active layer monitoring across the sporadic, discontinuous and continuous permafrost zones, Mackenzie valley, northwestern Canada. 7th International Conference on Permafrost, Yellowknife, Canada, pp. $815-820$.

Osterkamp, T.E., Gosink, J.P., 1991. Variations in permafrost thickness in response to changes in paleoclimate. Journal of Geophysical Research 96 (B3), 4423-4434.

Pelfini, M., 1992. Le fluttuazioni glaciali oloceniche nel gruppo Ortles-Cevedale (settore lombardo). $\mathrm{PhD}$ thesis, Università degli Studi di Milano.

Pelfini, M., 1999. La piccola età glaciale e la sua registrazione negli archivi naturali (alcuni esempi nelle Alpi Italiane). In: Orombelli, G. (Ed.), Studi geografici e geologici in onore di Severino Belloni. G. Brigati, Genova, pp. 525-546.

Romanovsky, V.E., Osterkamp, T.E., 1995. Interannual variations of the thermal regime of the active layer and near surface permafrost in northern Alaska. Permafrost and Periglacial Processes 6, 313-335.

Smith, M.W., 1975. Microclimatic influences on ground temperatures and permafrost distribution, Mackenzie Delta. Canadian Journal of Earth Science 12, 1421-1438.

Wang, K., 1992. Estimation of ground surface temperatures from borehole temperature data. Journal of Geophysical Research 97 (B2), 2095-2106. 